\title{
LEITURA DAS RELAÇÕES PROFESSOR-ALUNO NO ENSINO SUPERIOR: UMA PERSPECTIVA DECOLONIAL E INCLUSIVA
}

\author{
Leandro V. Delcaro*, Norma S. T. Lima.
}

\section{Resumo}

Trata-se de um estudo exploratório, quali-quantitativo, inspirado em inquietações discentes referentes ao ensino superior. Indaga se a colonialidade do poder, saber e do ser estão presentes na relação professor-aluno no ensino superior público paulista. Toma como referencial teórico, as discussões do Grupo Modernidade/Colonialidade, destacando-se: Mignolo e Walsh, além de Boaventura de Sousa Santos, e estudos sobre inclusão, como princípio educativo. Conclui-se, parcialmente que, se por um lado, é recorrente sentimentos de subalternização, já naturalizados nas experiências dos alunos-respondentes, quando na presença de alguns professores, por outro, apontam a importância dos professores em suas formações.

Palavras-chave:

Professor-aluno, ensino superior, colonialidade.

\section{Introdução}

A existência de uma hegemonia epistêmica eurocêntrica, racista, sexista e machista na sociedade moderna ratifica uma produção de ausência de sujeitos e saberes outros, por meio de uma desvalorização e ocultamento de grupos sociais e suas experiências, gerados historicamente, por meio da colonialidade do poder, saber e do ser. A problemática deste estudo refere-se a suspeita de que a desvalorização e ocultamento dos sujeitos e saberes outros a partir da colonialidade do poder, saber e do ser fazem-se presentes no ensino superior público, especificamente, no caso desta pesquisa, na relação professor-aluno

Os estudos decoloniais problematizam mecanismos e processos de subalternização construídos por uma matriz de poder colonial e buscam condições de visibilidade à luta de pessoas/grupos e suas práticas epistêmicas contra a colonialidade, propondo uma reconstrução epistêmica radical destas formas de exclusão.

A abordagem inclusiva adotada, refere-se a uma noção ampliada. Própria de um princípio educativo constitucional, não se reporta a um atributo, seja este, raça, gênero, deficiência, ou outro, mas ao questionamento de fronteiras e critérios de pertencimento e legitimidade de saberes que posicionam os sujeitos nas relações sociais.

\section{Resultados e Discussão}

A coleta e construção de dados ocorreu por meio de formulário on-line na plataforma Google Forms, para estudantes de diferentes áreas de uma universidade pública paulista. Buscou-se identificar as principais tensões presentes nas relações professor-aluno, e percepções discentes destas relações, destacando-se sentimentos recorrentes.

Foram obtidas 68 respostas e o sentimento de exclusão e subalternidade foi comum entre os respondentes. Respectivamente, 47 e 55 discentes relataram a presença destes sentimentos nas relações professor-aluno, durante a formação acadêmica na Universidade. Vergonha, medo, insegurança e sentimento de inferiorização perante o professor se mostraram recorrentes.
Você já se sentiu subalterno/inferior na relação professor-aluno? 68 respostas
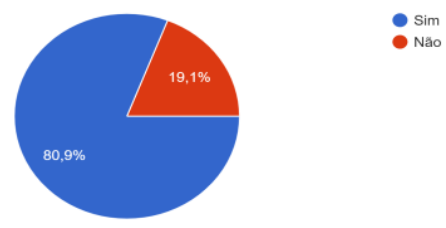

Figura 1. Gráfico referente ao sentimento discente sobre sua subalternização na relação professor-aluno.

Qual a nota para sua experiência nas relações com professores?

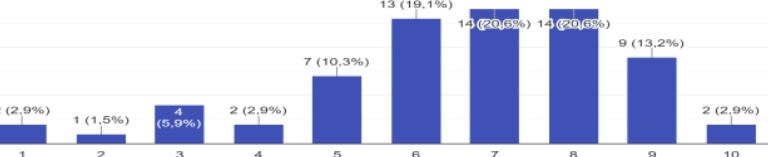

Figura 2. Gráfico referente à percepção discente em relação a experiência geral com os docentes.

\section{Conclusões}

Uma análise parcial dos dados, articulados aos estudos sobre decolonialidade e inclusão apontam sentimentos de subalternização naturalizados nas experiências dos alunos-respondentes, quando na presença de alguns professores.

LIMA, N. S. T. DE; MANTOAN, M. T. E. Notas sobre inclusão, escola e diferença. ETD - Educação Temática Digital, v. 19, n. 4, p. 824-832, 6 out. 2017.

MANTOAN, Maria Teresa Eglér. Inclusão escolar: o que é? por quê? como fazer? São Paulo: Summus, 2015.

MIGNOLO, Walter D.. COLONIALIDADE: o lado mais escuro da modernidade. Revista Brasileira de Ciências Sociais, [s.1.], v. 32, n. 94, p.1-18, jun. 2017.

SANTOS, Boaventura de Sousa; MENESES, Maria Paula. In Epistemologias do Sul. São Paulo: Cortez, 2010. p. 15-27.

WALSH, Catherine. Interculturalidade Crítica e Pedagogia Decolonial: in-surgir, re-existir e re-viver. In: CANDAU, Vera Maria (Org.). Educação Intercultural na América Latina: entre concepções, tensões e propostas. [s. L.]: 7 Letras, 2009. p. $12-41$. 